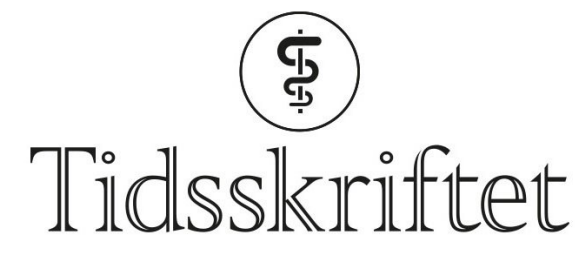

DEN NORSKE LEGEFORENING

\title{
Resorberbare stenter gir flere bivirkninger
}

FRA ANDRE TIDSSKRIFTER

ØYVIND STOPLE SIVERTSEN

Tidsskriftet

Forekomsten av stentrelaterte hendelser var høyere hos hjertepasienter som fikk resorberbar stent sammenlignet med dem som fikk metallstent. Det viser en ny metaanalyse.

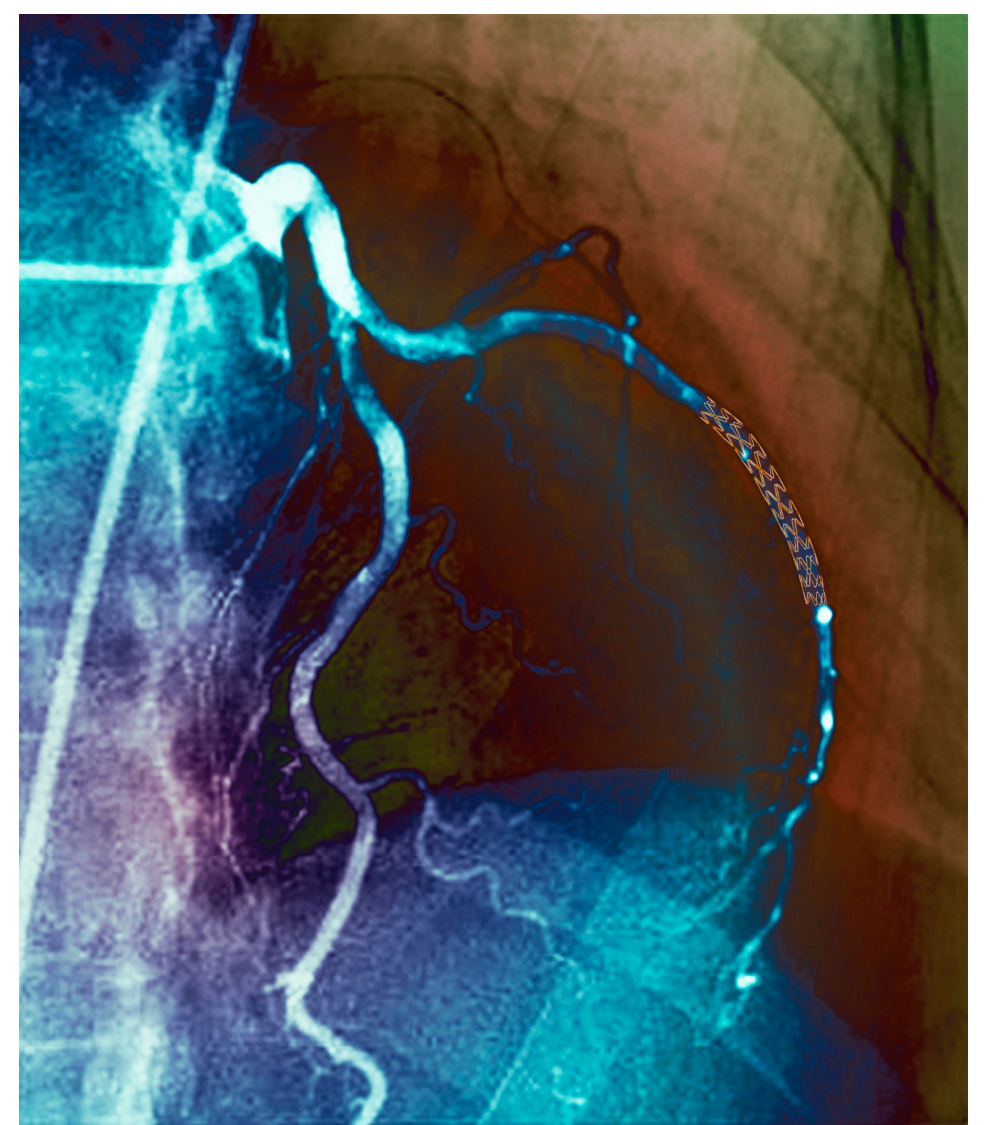

Farget angiogram av koronararteriene hos en 52-åring, der arterien til høyre er stentbehandlet. Foto: Science Photo Library

Resorberbare stenter som erstatning for metallstenter har vært ansett som et lovende alternativ ved behandling av okkluderte koronararterier. Nå viser en nylig publisert metaanalyse i The Lancet at det fremdeles er et stykke igjen før disse behandlingene er likeverdige (1). 
Metaanalysen er basert på sju studier, der til sammen 5583 pasienter ble randomisert til behandling med enten resorberbar stent $(\mathrm{n}=3261)$ eller medikamentfrigjørende metallstent $(n=2322)$. Det var signifikant forskjell i forekomsten av uønskede hendelser (det vil si infarkt relatert til behandlet arterie eller behov for revaskularisering av den aktuelle arterien) etter 1-2 år og etter to års oppfølging. Uønskede hendelser ble registrert hos 9,4\% av dem med resorberbar stent, mot 7,4\% av dem med metallstent.

- Denne metaanalysen bekrefter på en overbevisende måte at forekomsten av stentrelaterte hendelser er mye høyere hos pasienter som har fått resorberbar stent sammenlignet med moderne, medikamentfrigjørende metallstenter, sier Christian Eek ved Hjertemedisinsk avdeling, Oslo universitetssykehus.

- Den initiale entusiasmen omkring resorberbare stenter har kjølnet betraktelig, både i Norge og internasjonalt, etter mange rapporter om overhyppighet av stenttromboser og andre komplikasjoner, og produktet er nå kun tilgjengelig til bruk i studier. De teoretiske fordelene ved en resorberbar stent er så langt ikke sannsynliggjort i kliniske studier. Hendelsesraten knyttet til moderne medikamentfrigjørende metallstenter er lav, og ytterligere forbedringer ved bruk av resorberbart materiale vil være vanskelig å oppnå, sier Eek.

\section{LITTERATUR:}

1. Ali ZA, Serruys PW, Kimura T et al. 2-year outcomes with the Absorb bioresorbable scaffold for treatment of coronary artery disease: a systematic review and meta-analysis of seven randomised trials with an individual patient data substudy. Lancet 2017;390: 760 - 72. [PubMed][CrossRef]

Publisert: 2. oktober 2017. Tidsskr Nor Legeforen. DOI:10.4045/tidsskr.17.0732

(C) Tidsskrift for Den norske legeforening 2020. Lastet ned fra tidsskriftet.no 